The "Petrefactenkunde Deutschlands" was Quenstedt's greatest work; the first volume was issued in 1849 , and the eighth and last in 1884: it has been calculated that there are no less than 19,029 specimens figured and described in this work. Jurassic palæontology is especially well treated in the Petrefacta, and also in Quenstedt's "Handbuch der Petrefaktenkunde," the three editions of which appeared in 1852,1867 , and 1885 respectively; he made further contributions to the knowledge of the fauna of the same system in an extensive series of memoirs. The Cephalopoda was his favourite group: it formed the subject of both his first and last palæontological works, viz. his doctoral thesis in 1836 , "De notis nautilearum primariis," and "Die Ammoniten des schwäbischen Jura," concluded a few months before his death. But though palæontology became the chief work of his life, as was naturally the case with a geologist living among the rich Jurassic rocks of Würtemberg, Quenstedt did not neglect his first love, mineralogy, and his "Metbode der Krystallographie" (1840), his well-known " Handbuch der Mineralogie" (1854, 1863, and 1877), and his "Grundriss der bestimmenden und rechnenden Krystallographie" (1873), were his principal publications upon this sulject. Probably no German geologist was more prolific of big books than Prof. Quenstedt, and the fact that he accomplished so much is no doubt to be explained by his retention in after-life of the indefatigable energy, the simple life, and abstemious habits, which characterized him in his student days. Born of the people, he was always in touch with them, and he never used the title "von," which had been granted him; his popular works, "Sonst und Jetzt" (1856), " Epochen der Natur" (1861), and "Klar and Wahr" (1872), showed how deeply he felt the need of the popularization of scientific education. His success in forming so valuable a collection from the Würtemberg Jura is probably as much due to the interest in geology spread by his writings as to his own personal popularity with the people among whom he lived so long and laboured so well.

\title{
MELCHIOR NEUMAYR.
}

BorN 24TH OCTOBER, 1845; DIED 29Th JANUARY, 1890.

Melchior Neumayr was born in Munich on 24th October, 1845, but spent most of his childhood in Stuttgart, where his father was the Bavarian Ambassador. As the son of a family that has borne an honoured name in the annals of Bavarian history, Neumayr was destined for political service, and after leaving the Gymnasium of Munich, he commenced a course of legal studies in the University of that city. Here, howerer, his enthusiasm for science manifested itself, and led him to abandon law for geology and palæontology, the better to study which he proceeded to Heidelberg. After gaining his Ph.D. at this University, he returned to Bavaria, and worked under Gümbel on the geological survey of that state. After a few months' training he joined in 1868 the service of the Austrian Geologische Reichsanstalt as a volunteer; in the same year 
he issued his first paper in conjunction with Dr. Guido Stache on "Die Klippen bei Lublau und Jerembina." $\mathrm{He}$ soon secured an appointment on the paid staff of the Survey, on which he remained till 1872. He was engaged mainly in the Tyrol, the Vorarlberg, and the Carpathians, and it was no doubt the work during this period that fixed the bent of Neumayr's genius, as, after facing for four years the great geological problems connected with those districts, it was impossible for him to settle down as merely a laboratory palæontologist. At the same time Neumayr was not indifferent to the mountains for their own sake: be soon became a keen climber and an energetic member of the Deutscher und Oesterreich Alpin Verein; in spite of the many calls upon his time, he served for a year as secretary to this, the greatest of the Alpine Clubs, and only withdrew from the rolls of officers on his return to Germany in 1872. Though in later years heart disease prevented his active participation in Alpine work, be followed it with unflagging interest, and was to the last a fairly regular contributor to the Mittheilungen of the Deutscher und Oesterreich Alpin Verein.

In 1872 Neumayr resigned his post on the Austrian Reichsanstalt, and returned to Heidelberg; but in the succeeding year he was recalled to Vienna as Extraordinary Professor of Palæontology, a chair then created. In 1874 he made a geological excursion to Northern Greece and the Erean; he climbed Athos and Olympus, and worked out and described the sequence of schists, gneisses and marbles of which the former mountain is composed. In 1879 he was appointed to the Ordinary Professorship at Vienna, a post he beld till his death.

Though Neumayr's scientific work was executed in but little over twenty years, it was unusually fruitful in interesting results. His writings may be divided into three classes: First, his more popular works, such as his well-known "Erdgeschichte" (1887), and some of his papers on mountain structure, such as that recently issued on "Bergstürze." Secondly, his petrographical and stratigraphical papers beginning with his "Petrographischen Studien uber mittleren und oberen Lias Wurtembergs" (1868 and 1870), and his "Dogger und Malm in Penninischen Klippenzug" (1869) ; besides a series on the Jurassic, there are his "Das Schiefergebirge der Halbinsel Chalkidike und der thessalische Olymp" (1876); and a valuable series giving the results of his Egean tour, published in 1881 ; later still his paper "Die krystallinischen Schiefergebirge in Attika" (1884), shows that he always retained his interest in petrographical problems.

The papers of the third class, the more strictly palæontological, form a very lengthy list, touching on most divisions of the Animal Kingdom. The groups upon which Neumayr wrote most frequently were the Jurassic Cephalopods and the freshwater Mollusca of the Vienna basin; but valuable papers stand to his credit on the Fornminifera, Colenterata, and Echinodermata; his first memoir on the last group, "Morphologische Studien über fossilen Echinodermen," was an especially original and suggestive piece of work. Nor did 
he confine himself to the Invertebrates, for he wrote more than once on the Mammalia. Neumayr's knowledge of the Jurassic fauna and geology was exceptionally wide, and upon it was based the brilliant generalizations as to the zoological regions and climatic zones of that period, which mark out the series of papers commenced under the title of "Jura-studien" as his masterpiece. The "Stämme des Thierreichs" was the last of his larger works, and of this only one volume has been issued: in this he dealt with the Protozoa, Coelenterata, Echinodermata, Vermes, and Molluscoidea, treating each group with a master-hand and in an original method. The second volume would have been even better, for if Neumayr could be charged with being a specialist, it would have been in connection with two of the classes there to have been discussed. He also projected an "Index Palæontologicus"; but this with many other plans of his has been frustrated by bis death.

But though it may be convenient to group his work under these three divisions, Neumayr was too true a palæontologist for any rigid classification to be possible on such lines. Palæogeography was with him inseparably connected with palæontology, and his work on the former subject compelled him to keep abreast with the progress in other branches of geological work. Neumayr did not regard palæontology as a mere branch of zoology, and, keen evolutionist though he was, fossils had for him a higher value than that which they possess from their bearing on the origin of the existing fauna. He was, of course, interested in this aspect of the question, and probably no better work has been done in tracing descent among the invertebrates than bis "Berkunft der Unionen" and his "Die natürliche Verwandtschaftsverhältnisse der schalentragenden Foraminiferen." But it would be unjust to Neumayr to regard him as a phylogenist alone, or to attach most value to his work in this field : the most original work in his "Stämme" was his reclassification of the Crinoidea, which marked a great adrance when the compositor set it up; but it was out of date before the sheets had left the press. His discoveries in other subjects are of much more pernanent value, and it is probably for these that he will be best remembered. $\mathrm{He}_{e}$ has, in fact, been recently described as a " palæogeographer" rather than a palæontologist, but this he would probably have regarded as a slurring limitation on his favourite branch of science. Neumayr's qualifications for the discussion of questions of the physical geography of the past were simply unique, and it is probably here that he will be most missed. Considering the powerful work of his early manhood, still more brilliant achievements might have been expected from the efforts of his maturer years. But the beart disease that had so long afflicted him struck him down in the very prime of life, just when his mastery of Jurassic palæontology, his thorough acquaintance with stratigraphical literature and his sound knowledge of the principles of physical geology, seemed most in demand for the solution of the problems that he knew so well how to bandle. 